\section{Reports and Publicutions}

not included in the Monthly Books Supplement

\section{Great Britain and Ireland}

Proceedings of the Royal Irish Academy. Vol. 71, Section A, No. 7: Runge Domains in Banach 71 , Section B, No. 18: Growth and Food of Brown Trout Salmo trutta (L) in Irish Waters. By $\mathbf{M}$. Kennedy and P. Fitzmaurice. Pp. 269-352+ plates 8-12.) 11.45. (Dublin: Royal Irish Academy, Cotton Research Corporation 1921 to 1971 . (In celebration of the Golden Jubilee of the Cotton Research Corporation, and of the donation of its Cotton Research Station, Namulonge, to the Government of Uganda on 1st January 1972.) Pp. 28. (London: Cotton Research Corporation, 1971.) [31 Visual Media in Geography and Geology-a Con-
ference Report, 30th January 1971, National Film ference Report, 30th January 1971, National Film
Theatre, South Bank, London. Pp. 57. (London: Theatre, South Bank, London. Pp. 57. (London:
British Universities Film Council, 1971.) 65p. [31 British Medical Bulletin, Vol. 28, No. 1 (January
1972): Symposium on Research in Diseases of the 1972): Symposium on Research in Diseases of the Tropics. Pp. 1-102. (London: The British Coun-
cil, 1972.) $£ 2.25$. Young Fabian Pamphlet No. 28: The Universities-Pressures and Prospects. By Colin Crouch and Stephen Mennell. Pp. 47. 45p. Fabian Reists Now? By S. F. Kissin. Pp. 36, 40p. (London: Fabian Society, 1972.) Wool Industries Research Assogiation. Report 1972.) Accounts 1971. Pp. 26. (Leeds: WIRA.

The Zoological Record. 1968, Vol. 105, Section 2: Protozoa, Part 1 (Recent) and Part 2 (Fossil). Compiled by the Staff of the Zoological Society of 11. Trilobita. Compiled by Sir James Stubblefield, FRS. Pp. 55. £5. (London: The Zoological Society
of London, 1971.)

The Scientific Proceedings of the Royal Dublin Society. Series A. Vol. 4, No. 6: Cleavage Polyembryony in Conifers and Taxads-a Survey. 1. and M. Brennan. Pp. 57-88. \&1. Vol. 4, No. 7: Ordovician Ash-Fall Tuffs from Co. Waterford. By 4. J. Stillman. Pp. 89-102+ plates 4-6. 50p. Vol. 4, No. 8: A New Look at the Rosslare Complex. By Michael D. Max and N. B. Dhonau. Pp. 103-
$120+$ plate 7. 50p. Series B. Vol. 3, No. 1: Age

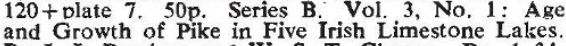
By J. J. Bracken and W. S. T. Champ. Pp. 1-34,
75 p. Vol. 3, No. 2: Limits of Weichsel Glacial Deposits in the South Tipperary Area. By T. F.
Finch. Pp. 35-42. 36p. Vol. 3, No. 3: The Control of the Fox, Vulpes vulpes (L.). Populations in Northern Ireland. By J. S. Fairley. Pp. $43-48$. bution of the Arthronod Fauna of an Old Grassland Soil. By J. P. Curry. Pp. 49-72. 75p. Vol. 3. No. 5: Myzus persicae (Sulz) and other Aphids Occurring on Sugar Beet in Ireland and Their Importance as Vectors of Virus Yellows, By R. Dunne.
Pp. 73-80. 40p. Vol. 3, No. 6: The Occurrence and Control of Pigmy Mangel Beetle. Atomaria Linearis (Steph) in Ireland. By A. M. Feeney. Pn. 81-86. 40p. Vol. 3, No. 7: A Comparison of Soils on Coal Measures in S.W. Ireland and S.E. Wales. By C. B. Crampton and T. F. Finch. Pp. 87-100. 45p. (Dublin: The Royal Dublin Society, 1971.) [512 Bulletin of the British Museum (Natural History). Entomologv. Vol. 26, No. 8: A Revision of Francis (Diptera). By Kenneth George Valentine Smith.
Pp. $345-370+3$ plates. f1.20. Zoology. Vol. 22, No. 2: The Clupeoid Fishes Described by Francis Day. By P. K. Talwar and P. J. P. Whitehead
Pp. 57-85+2 plates. $£ 1.20$. Vol. 22, No. 3: Fin Structure of Bodo saltans and Bodo caudatus (Zoomastigophora: Protozoa) and Their Affinities with the Try panosomatidae. By B. E. Brooker. Pp. 87 History), 1971.) (London: British Museum (Natura Fabian Research Series No. 298: Collective Bargaining and Inequality. By Jim Skinner. Pp. 20 The Edinburgh School of Agriculture. Experimental Work 1970. Pp. 146 AEdinburgh: Edin[7] Doom or Deliverance?- The Dogmas and Duties of a Technological Age. By the Right Reveren 30. (Manchester: Manchester University Press 1972.) 49p net.

Friends of the rake District. Report and N10 Letter, January 1972. Pp. 18, (Kendal: Friends of
the Lake District, 27 Greenside, 1972.) [111

The Medical Research Council of Ireland Annual The Medical Research Council of Ireland. Annual 79. (Dublin: The Medical Research Council Pp. Ireland, 1972.) $25 \mathrm{p}$

Science Research Council, Radio and Space Re search 1968-1970 The Report of the Director of the Radio and Space Research Station. Pp. iii + 59 (London: HMSO, 1971.) 80p net.

Progress Reports from Experiment Stations. Seaon 1970-71. Uganda. Pp 82. (London: Cotto Research Corporation, 1971.) 30p.

Beef Processing and Marketing: Proccedings of an International Symposium held in Dublin on April 28 stock and Meat Commission; Institute of Food Science and Technology.) Pp. 108. (Dublin An ₹1.50

[121

\section{Other Countries}

Smithsonian Contributions to Zoology, No. 58: Keys to the Hawaiian Marine Gammaridea, 0-30 Meters. By J. Laurens Barnard. Pp. iii +135 1971. For sale by US Government Printing Office.) $\$ 1.75$.

US Department of the Interior: Geological Survey. Techniques of Water-Resources Investigations of the United States Geological Survey. Chapter A2: Determination of Minor Elements in Water by Emission Spectroscopy. By Paul R. Barnett and Government Printing Office, 1971.) 50 cents. [6] Australia: Commonwealth Scientific and Industria Research Organization. Division of Soils Technical Papers. No. 8: Basic Exchangable Cations in Soils. By B. M. Tucker. Pp. 22. No. 9: The Calculation of Results in Electron-Probe Microanalysis. By A. C. Oertel. Pp. 26. No. 10: A Storage and Retrieval System for Micromorphological Descriptions of Soils. By (The Late) J. M. Norris, S. W. Cumpston and J. R. Sleeman. Pp. 20. (Melbourne:
CSIRO, 1971.) Australia: Commonwealth Scientific and Indusrial Research Organization. Annual Report of the Division of Animal Health for 1970. Pp. 95. (Melbourne: CSIRO, 1971.)

Smithsonian Contributions to Earth Sciences. No 7: Geology of the Lincoln Area, Lewis and Clark Country, Montana. By William G. Melson. Pp. 29. 40 cents. Smithsonian Contributions to Paleobiology. No. 9: Catalog of Type Specimens of Invertebrate Fossils-Conodonta. Compiled by
Frederick J. Collier. Pp. 256. \$2.50. Smithsonian
Contributions to Zoology. No. 84: Butterflies of the Genus Vanessa and of the Resurrected Gener Bassaris and Cynthia (Lepidoptera: Nymphalidae) New Approach in the Analysis of Biogeographic Data. By James A. Peters. Pp. 28.40 cents. No Kinber of Two Now Genta of Two New Genera. By Marian H. Pettibone Pp. tution Press, 1971. For sale by US Government tution Press, 1971. For sale by US Government
[6] Smithsonian Contributions to Zoology, No. 104: Revision of Some Species Referred to Leptonereis, Nicon, and Laeonereis (Polychaeta: Nereididae). By Marian H. Pettibone. Po. 53. (Washington, DC US Government Printin Press, 1971. For sale by Darwin's Victorian Malady: Evidence for Its Medically Induced Origin. By John H. Winslow. (Memoirs of the American Philosophical Society, Vol 88.) Pp. 94. (Philadephia: American PhiloOrganization for Economic Co-operation and Development. Reviews of National Science PolicySpain. Pp. 123. (Paris: OECD; London: HMSO, US Department of the Interior: Geological Survey. Water-Supply Paper 1608-M: Hydrographic and Sedimentation Survey of Kajakai Reservoir, Afghanisian. By Don C. Perkins and J. K. Culbertson. Pp. iv + 43. (Washington, DC: Government Science Research Council of Canada. Backgroun Study for Science Council of Canada-Special Stud No. 21: Basic Research. By P. Kruus. Pp. 73. (Ottawa: Information Canada, 1971.) \$1.50. 110 US Department of the Interior: Gcological Survey. Water-Supply Paper 1908: Surface Water Rupply of the United States 1961-65. Part 3: Ohio Kanawha River to Louisville, Kentucky. Pp. viii + $581+1$ plate. \$3. Water-Supply Paper 1909: Surface Water Supply of the United States 1961-65. Part 3: Ohio River Basin. Vol. 3: Ohio River Basin from Louisville, Kentucky, to Wabash River.

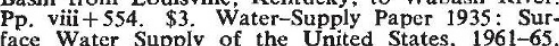
face Water Supply of the United States, 1961-65. Part 14: Pacific Slope Basins in Oregon and Lower
Columbia River Basin. Pp. $x+957+1$ plate. $\$ 4.50$. (Washington, DC: Government Printing Office.

US Department of the Interior: Geological Survey. Water-Supply Paper 1870-D : Summary of Floods in the United States during 1966. By J. O. Rostvedt et al. Pp. $\mathrm{v}+99$ (Washington, DC: Twenty-sixth Annual Report of the Council of the Queensland Institute of Medical Research fo the year ended June 30, 1971. Pp. 23. (Brisbane: Council of the Queensland Institute of Medica Research, 1971.

Annals of the Transvaal Museum. Vol. 27, No 8: The Southern African Subspecies of Nudaurelic cytherea (Fabricius, 1775) (Lepidoptera: Saturniidae). By H. Geertsema. Pp. 171-182+1 plate. Vol. 27 No. 9: Neue Lamiinae aus Südafrika (Coleoptera:
Cerambycidae). Von S. Breuning. Pp. 183-192. Cerambycidae). Von $S$. Breuning. Pp. 183-192. Vol. 27, No. 10: South African Lepldoptera, Descriptions of New Satyrinae (Lenidoptera: Nymphalidae). By L. Vari. Pp. 193-224+2 plates. Pretoria: Transvaal Museum, 1971.) [12] US Geological Survey. Bulletin 1018-U: Geology of the Near Islands, Alaska. By O. Gates. H. A Powers and R. E. Ailox. Pp. vil +709 . plates. Bulletin 1295: Bedrock Geology of Rhode Island. By Alonzo W. Quinn. Pp. y+68. (Wash-
ington, DC: Government Printing Office, 1971.) [131

\section{HOW TO BUY NATURE}

Volumes start in January, March, May, July, September and November, but subscriptions may begin at any time.

The direct postal price per subscription is:

12 MONTHS* (52 issues per title)

$\begin{array}{lcc} & \begin{array}{c}\text { Surface mail } \\ \text { UK and } \\ \text { worldwide } \\ \text { Nature (Friday) }\end{array} & \begin{array}{c}\text { U.S.A. and } \\ \text { Canada }\end{array} \\ \begin{array}{l}\text { Nature + } \\ \text { Nature Physical Science }\end{array} & \mathbf{£ 2 4} & \$ 48 \\ \begin{array}{l}\text { Nature + } \\ \text { Nature Now Biology }\end{array} & £ 24 & \$ 83 \\ \text { All three editions } & £ 29.50 & \$ 108 \\ \text { Annual Index } & £ 1 & \$ 3\end{array}$

* Rates for shorter periods pro rata (minimum three months) (Charge for delivery by air mail on application)
Editorial and Publishing Otfices of NATURE

MACMILLAN JOURNALS LIMITED

4 LITTLE ESSEX STREET, LONDON WC2R 3LF

Telephone Number : 01-836 6633. Telegrams : Phusis London WC2R 3LF Tolex 262024

711 NATIONAL PRESS BUILDING WASHINGTON DC 20004

Telephone Number : 202-737 2355. Telex 64280 Subscription Department

MACMILLAN JOURNALS LIMITED

BRUNEL ROAD BASINGSTOKE, HANTS

Telephone Number : Basingstoke 29242

American display advertisements

NATURE SCIENTIFIC PUBLICATIONS INC

711 NATIONAL PRESS BUILDING WASHINGTON DC 20004

All other advertisements

T. G. SCOTT \& SON, LIMITED

1 CLEMENT'S INN, LONDON WC2A 2ED

Telephone : 01-242 6264/01-405 4743

Telegrams : Textualist London WC2A 2ED

Registered as a newspaper at the Post Office

Copyright (C) Macmillan Journals Limited, March 171972 